Journal of Health Education

\title{
Association of Health Service Quality with Patient Satisfaction in Primary Healthcare Center of Gedongtengen Yogyakarta
}

\author{
Yoan Ajeng Mustika ${ }^{1 \bowtie}$, Jacoba Nugrahaningtyas Wahjuning Utami ${ }^{1}$, Sukismanto Sukismanto ${ }^{2}$ \\ ${ }^{1}$ Department of Midwifery, Faculty of Health Sciences, Universitas Respati Yogyakarta, Indonesia \\ ${ }^{2}$ Department of Public Health, Faculty of Health Sciences, Universitas Respati Yogyakarta, Indonesia
}

\section{Article Information \\ Article history: \\ Submitted: March 2019 \\ Accepted: March 2019 \\ Published: April 2019}

Keywords:

Dimension of Quality;

Satisfaction;

Patients Satisfaction

\begin{abstract}
Background: Quality of service is an important indicator in measuring patient satisfaction. Based on the results of a preliminary study in 10 patients, in terms of the dimension of reliability quality, $30 \%$ said satisfied and $70 \%$ less satisfied; in terms of the dimension of empathy quality, 20\% said very satisfied and $80 \%$ satisfied; in terms of the dimension of assurance, $90 \%$ said satisfied and $10 \%$ unsatisfied; in terms of the dimension of responsiveness, $10 \%$ said very satisfied, $80 \%$ satisfied and $10 \%$ less satisfied; in terms of the dimension of tangible, $90 \%$ said satisfied and $10 \%$ less satisfied. the aim of this study is to identify the association between dimension of health service quality and patient satisfaction in Maternal \& Child Health and Family Planning Polyclinic at Primary Healthcare Center (PHC) of Gedongtengen, Yogyakarta.

Methods: This research employed a descriptive analytical method with cross sectional approach. The population consisted of 170 respondents. Samples were taken using purposive sampling, resulting in 119 respondents as samples. Data were statistically tested using Kendall's Tau.

Results: The results of statistical test indicated that there was a correlation between the dimension of reliability, empathy, assurance, responsiveness, and tangible to patient satisfaction.

Conclusion: There are correlations of the dimensions of reliability, empathy, assurance, responsiveness and tangible with patient satisfaction.
\end{abstract}




\section{BACKGROUND}

Every patient is a special person who wants to be treated specifically, patients have their own personality, desires and unique reasons for dropping the choice for choosing Primary Healthcare (PHC) services. If the PHC treats it as a special person and solves that unique problem, then the patient will definitely continue to be a PHC patient.

Knowledge and skills of health workers are balanced with the completeness of the facilities will provide maximum service so that it will be able to reduce and overcome health problems that arise in the community. The quality of existing services is expected to provide satisfaction in accordance with what is expected by the community as patients in obtaining health services that are in accordance with their needs (Andriani, 2017).

Indicators of hospital inpatient satisfaction can be applied by improving hospital service management so that patient satisfaction can be realized. In addition, for patients the quality of service can be used as a factor to choose a quality hospital (Susmaneli, 2014).

One important element in improving the quality of services at the PHC is the Maternal and Child Health $(\mathrm{MCH})$ service and Family Planning (FP) services. According to the Decree of the Minister of Health No. 75 of 2014 concerning $\mathrm{PHC}, \mathrm{MCH}$ services and $\mathrm{FP}$ services is one of the basic six programs that must be held by each health center in the territory of Indonesia. $\mathrm{MCH}$ and family planning services have an important role in improving national health status because mothers and children are important elements in nation building.

The Community Satisfaction Survey is a comprehensive measurement of activities about the level of community satisfaction obtained from the measurement results of community opinion in obtaining services from the provision of public services. The quality of health care workers in the PHC in Yogyakarta has been good with the title. Based on the service unit's Community Satisfaction Survey (CSS $\mathrm{t} / \mathrm{n}$ SKM), Yogyakarta, PHC of Gedongtengen has a value of $74.05 \%$, PHC of Gondokusuman I $74.95 \%$, PHC of Wirobrajan 76.52\%, PHC of Kota Gede I 76.54\%, and PHC of Tegalrejo
$76.65 \%$ which is ranked lower compared to 18 PHC in the city of Yogyakarta.

Community satisfaction as a whole from the element of service in PHC of Gedongtengen, based on the dimensions of health service quality, on the reliability dimension has a value of $71.74 \%$, empathy dimension $73.41 \%$, assurance dimension $75.9 \%$, responsiveness 76 , $30 \%$, and on the tangiable dimension (physical evidence or direct evidence) $71.39 \%$.

The results of a preliminary study conducted at the PHC of Gedongtengen in Yogyakarta, from 10 respondents in the dimensions of reliability quality $30 \%$ said they were satisfied and $70 \%$ said they were dissatisfied, on the four quality dimension $20 \%$ said they were very satisfied and $80 \%$ said they were satisfied $10 \%$ said they were not satisfied, on the responsive dimension of $10 \%$ said they were very satisfied, $80 \%$ said they were satisfied, and $10 \%$ said they were not satisfied, in the tangible dimension $90 \%$ said they were satisfied and $10 \%$ said they were not satisfied. The aim of this study is to identify the association between dimension of health service quality and patient satisfaction in Maternal \& Child Health and Family Planning Polyclinic at Primary Healthcare Center (PHC) of Gedongtengen, Yogyakarta.

\section{METHOD}

This study used descriptive analytical research. The research design used was cross sectional. This research was conducted at the $\mathrm{MCH}$ and FP Polyclinic PHC of Gedongtengen Yogyakarta for several days.

The population in this study were all patients who came to the $\mathrm{MCH}$ polyclinic and FP PHC of Gedongtengen Yogyakarta in April 2017 as many as 170 respondents.

Sampling in this study using a non random sampling system with accidental sampling method as many as 119 respondents.

The instrument uses questionnaires on the quality dimensions of health services and patient satisfaction. Validity and reliability test using conteng validity test. The data were analyzed using frequency distribution analysis and Kendall's bivariate analysis.

Dimensions of service quality according to include tangibles, reliable, responsive, assur- 
ance and empathy. These overall dimensions always change dynamically depending on the quality of service. Patient satisfaction must always be assessed periodically so it can be a reference material and evaluation for hospitals to to improve service quality (Sower et al, 2001)

\section{RESULTS AND DISCUSSION}

Respondents' characteristics were based on the age of the respondents in the $\mathrm{MCH}$ and FP Polyclinic PHC of Gedongtengen in Yogyakarta City, most of whom were included in the age group above 25 years as many as 78 respondents (65.5\%). Early adulthood based on psychosocial development is a time when an individual begins to develop a household and become a parent. Age is one of the factors that influence patient satisfaction where patient satisfaction is a patient evaluation.

Characteristics of respondents based on respondents' education in $\mathrm{MCH}$ and FP Polyclinic PHC of Gedongtengen in Yogyakarta City, most of them were respondents included in the SMA category as many as 82 respondents (68.9\%). Education is needed to get information such as things that support health so that it can improve the quality of life. Increasing one's health knowledge can be obtained from the results of listening experience, seeing information that gives certain results.

The characteristics of respondents were based on the work of the respondents in the $\mathrm{MCH}$ and FP Polyclinic PHC of Gedongtengen in Yogyakarta City, most of whom were respondents included in the IRT category as many as 74 respondents $(62.2 \%)$. Work is one of the factors that influence consumer perceptions of the quality of health services.

The Reliability Dimension in $\mathrm{MCH}$ and FP Polyclinic PHC of Gedongtengen in Yogyakarta City, the characteristics of reliability are based on the MCH and FP Polyclinic PHC of Gedongtengen in Yogyakarta City, most of the respondents consider the reliability dimension as good as 85 respondents (71.4\%). Reliability is the company's ability to provide services in accordance with the promised accurately and reliably. Reliability is the ability to carry out the promised services appropriately and reliably. in general the majority of patients believe in the
Table 1. Univariate analysis result

\begin{tabular}{|c|c|c|}
\hline Dimension & Frequencies & $\%$ \\
\hline \multicolumn{3}{|l|}{ Reliability } \\
\hline Not good & 0 & 0 \\
\hline Less good & 7 & 51.9 \\
\hline Good enough & 85 & 71.4 \\
\hline Good & 27 & 22.7 \\
\hline \multicolumn{3}{|l|}{ Emphaty } \\
\hline Not good & 0 & 0 \\
\hline Less good & 0 & 0 \\
\hline Good enough & 29 & 24.4 \\
\hline Good & 90 & 75.6 \\
\hline \multicolumn{3}{|l|}{ Assurance } \\
\hline Not good & 0 & 0 \\
\hline Less good & 2 & 1.7 \\
\hline Good enough & 44 & 37.0 \\
\hline Good & 73 & 61.3 \\
\hline \multicolumn{3}{|l|}{ Responsiveness } \\
\hline Not good & 0 & 0 \\
\hline less good & 0 & 0 \\
\hline Good enough & 40 & 33.6 \\
\hline Good & 79 & 66.4 \\
\hline \multicolumn{3}{|l|}{ Tangible } \\
\hline Not good & 0 & 0 \\
\hline Less good & 0 & 0 \\
\hline Good enough & 42 & 35.3 \\
\hline Good & 77 & 64.7 \\
\hline \multicolumn{3}{|c|}{ Patient satisfaction } \\
\hline Very satisfied & 38 & 31.9 \\
\hline Satisfied & 79 & 66.4 \\
\hline Less satisfied & 2 & 1.7 \\
\hline Not satisfied & 0 & 0 \\
\hline
\end{tabular}

reliability and accuracy of the services provided by officers quickly. As well as the reliability possessed by officers, officers are able to be fair in providing services to patients without distinguishing social status or other factors (not being discriminatory) (Kuntoro, 2017). Besides that, the service schedule at the MCH and FP Polyclinic is on time and the waiting time (queue) is not too long. Patients find services that match what they expect. Patients agree that admission and service procedures tend to be smooth.

Patient Assessment Dimension (Em- 
pathy), the characteristics of the respondents based on empathy in the $\mathrm{MCH}$ and FP Polyclinic PHC of Gedongtengen in Yogyakarta City, most respondents considered the empathy dimension as good as 90 respondents (75.6\%). Empathy is a condition for caring, giving personal attention to patients. Some of the things that support good service attention are the majority of patients have received genuine attention from health workers. The clerk is able to understand the needs of the patient, and is able to provide motivational encouragement to the patient's problems. Officers always treat patients well and do not discriminate patients in providing services.

The Patient Assessment of Assurance Dimensions (Assurance), that the characteristics of the respondents are based on the assurance dimension at the $\mathrm{MCH}$ and FP Polyclinic PHC of Gedongtengen in Yogyakarta City, the majority of respondents consider that the guarantee dimension is good, namely 73 respondents (61.3\%). Assurance is knowledge, politeness and the ability of company employees to foster trust in patients to the company, including knowledge, ability, politeness, and the trustworthy nature of the officer, free from the dangers of risk and doubt. Guarantees include the ability to know the product / service appropriately, the quality of hospitality, attention and politeness in providing services, skills in providing information, ability to provide security in utilizing the services offered, and the ability to instill patient trust in the company. According to Supartiningsih (2017) This can be interpreted if the trustworthy nature of employees increases, hospital patient satisfaction in Outpatient patients will also increase.

Responsiveness patient dimension assessments, Respondent characteristics based on responsiveness dimensions at in the $\mathrm{MCH}$ and FP Polyclinic PHC of Gedongtengen in Yogyakarta City, most respondents considered that the dimensions of responsiveness were good, namely 79 respondents (66.4\%). This shows that the assessment of most respondents about the ability of officers to provide services quickly, immediately respond to each patient's complaints, provide clear information about medical and therapeutic actions given, pay attention to each patient's needs, and the service flow is clearly informed is good. The existence of a group of patients who are dissatisfied with hospital services means that the whole aspect has not been optimal and can still be improved (Mumu, 2015)

Tangible dimension patient assessment (Physical Evidence or Direct Evidence), respondent characteristics based on tangiable dimensions (physical evidence or direct evidence) at the $\mathrm{MCH}$ and $\mathrm{FP}$ Polyclinic PHC of Gedongtengen in Yogyakarta City, most respondents considered that the physical evidence dimension was good, namely 77 respondents $(64,7 \%)$. Tangible (physical evidence or direct evidence) is the ability of a company to show its existence to external parties. Physical evidence is the appearance of physical facilities, equipment, personnel, and communication media. The appearance of polyclinic and health workers, the ability of polyclinic physical facilities and infrastructure, and the surrounding environment are clear evidence of the services provided by buyers of services. Service appearance is not only limited to the neat physical appearance of the room but also the appearance of the officers and the availability of supporting facilities and infrastructure.

Patient Satisfaction at $\mathrm{MCH}$ Polyclinic and FP PHC of Gedongtengen in Yogyakarta City, that the respondent's characteristics were based on patient satisfaction at the MCH Polyclinic and FP PHC of Gedongtengen in Yogyakarta City, most respondents considered that they were satisfied as many as 79 respondents (66.4\%). In line with research from Handayani (2016), of the five aspects assessed to determine the level of patient satisfaction with health services (outpatient) at Baturetno Health Center showed that patients were satisfied.

Bivariate analysis at this stage investigated the relationship of the reliability dimension with patient satisfaction at the $\mathrm{MCH}$ and FP Polyclinic PHC of Gedongtengen in Yogyakarta City using the Kendall Tau test that there was a significant relationship between the reliability dimension and patient satisfaction at the $\mathrm{MCH}$ and FP Polyclinic PHC of Gedongtengen in Yogyakarta City, with a significance value on the results showed $(\mathrm{p}=0.028<0.05)$. Research from Rahman et al (2013) to identify service quality factors that affect patient satisfaction 
Table 2. Bivariate Analysis

\begin{tabular}{|c|c|c|c|c|c|c|c|c|c|c|c|c|c|}
\hline \multirow{3}{*}{ Dimension } & \multicolumn{10}{|c|}{ Patient Satisfactory } & & & \multirow{3}{*}{ p value } \\
\hline & \multicolumn{2}{|c|}{$\begin{array}{l}\text { Very not } \\
\text { satisfied }\end{array}$} & \multicolumn{2}{|c|}{$\begin{array}{c}\text { Not } \\
\text { satis- } \\
\text { fied }\end{array}$} & \multicolumn{2}{|c|}{$\begin{array}{c}\text { Less } \\
\text { satisfied }\end{array}$} & \multicolumn{2}{|c|}{ Satisfied } & \multicolumn{2}{|c|}{$\begin{array}{c}\text { Very } \\
\text { satisfied }\end{array}$} & \multicolumn{2}{|c|}{ Total } & \\
\hline & $\mathrm{f}$ & $\%$ & $\mathrm{f}$ & $\%$ & $\mathrm{f}$ & $\%$ & $\mathrm{f}$ & $\%$ & $\mathrm{f}$ & $\%$ & $\mathrm{f}$ & $\%$ & \\
\hline \multicolumn{14}{|l|}{ Reliability } \\
\hline Not good & 0 & 0.0 & 0 & 0.0 & 0 & 0.0 & 0 & 0.0 & 0 & 0.0 & 0 & 0.0 & \multirow{4}{*}{0.028} \\
\hline Less good & 0 & 0.0 & 0 & 0.0 & 0 & 0.0 & 6 & 85.7 & 1 & 14.3 & 7 & 100 & \\
\hline Good enough & 0 & 0.0 & 0 & 0.0 & 2 & 1.7 & 59 & 69.4 & 24 & 28.2 & 85 & 100 & \\
\hline Good & 0 & 0.0 & 0 & 0.0 & 0 & 0.0 & 14 & 51.9 & 13 & 48.1 & 27 & 100 & \\
\hline \multicolumn{14}{|l|}{ Empathy } \\
\hline Not good & 0 & 0.0 & 0 & 0.0 & 0 & 0.0 & 0 & 0.0 & 0 & 0.0 & 0 & 0.0 & \multirow{4}{*}{0.001} \\
\hline Less good & 0 & 0.0 & 0 & 0.0 & 0 & 0.0 & 0 & 0.0 & 0 & 0.0 & 0 & 0.0 & \\
\hline Good enough & 0 & 0.0 & 0 & 0.0 & 2 & 6.9 & 24 & 82.8 & 3 & 10.3 & 29 & 100 & \\
\hline Good & 0 & 0.0 & 0 & 0.0 & 0 & 0.0 & 55 & 61.1 & 35 & 38.9 & 90 & 100 & \\
\hline \multicolumn{14}{|l|}{ Assurance } \\
\hline Not good & 0 & 0.0 & 0 & 0.0 & 0 & 0.0 & 0 & 0.0 & 0 & 0.0 & 0 & 0.0 & \multirow{4}{*}{0.005} \\
\hline Less good & 0 & 0.0 & 0 & 0.0 & 0 & 0.0 & 1 & 50.0 & 1 & 50.0 & 2 & 100 & \\
\hline Good enough & 0 & 0.0 & 0 & 0.0 & 2 & 4.5 & 35 & 79.5 & 7 & 15.9 & 44 & 100 & \\
\hline Good & 0 & 0.0 & 0 & 0.0 & 0 & 0.0 & 43 & 58.9 & 30 & 41.1 & 73 & 100 & \\
\hline \multicolumn{14}{|l|}{ Responsiveness } \\
\hline Not good & 0 & 0.0 & 0 & 0.0 & 0 & 0.0 & 0 & 0.0 & 0 & 0.0 & 0 & 0.0 & \multirow{4}{*}{0.016} \\
\hline Less good & 0 & 0.0 & 0 & 0.0 & 0 & 0.0 & 0 & 0.0 & 0 & 0.0 & 0 & 0.0 & \\
\hline Good enough & 0 & 0.0 & 0 & 0.0 & 1 & 2.5 & 32 & 80.0 & 7 & 17.5 & 40 & 100 & \\
\hline Good & 0 & 0.0 & 0 & 0.0 & 1 & 1.3 & 47 & 59.5 & 31 & 39.2 & 79 & 100 & \\
\hline
\end{tabular}

in private hospitals in Bangladesh with 390 respondents and using 11 quality dimension variables showed that reliability was significantly related to patient satisfaction.

Relationship between empathy (Empathy) and patient satisfaction states that there is a significant relationship between the dimensions of empathy (empathy) and patient satisfaction at the MCH and FP Polyclinic PHC of Gedongtengen in Yogyakarta City, with a significance value on the results $(p=0.001<0.05)$. In line with the research of Faisal et al. (2013) in a study of the relationship between care services and patient satisfaction in the Inpatient Installation of A BLU RSUP Prof. Dr. R.D. Kandou City of Manado with 85 respondents found a relationship between the dimensions of care (empathy) and satisfaction.

The relationship between the dimensions of Assurance and Patient Satisfaction states that there is a significant relationship between the dimensions of assurance (satisfaction) and patient satisfaction at the $\mathrm{MCH}$ and FP Polyclinic $\mathrm{PHC}$ of Gedongtengen in Yogyakarta City, with a significance value on the results ( $p=0.005$ $<0.05)$. Like Khamis \& Njau (2014) in a study of the level of patient satisfaction with the quality of health services in hospitals with 422 respondents found the assurance dimension was significantly associated with patient satisfaction.

The Relationship between Responsiveness Dimensions and Patient Satisfaction states that there is a significant relationship between the dimensions of responsiveness and patient satisfaction at the MCH Polyclinic and FP PHC of Gedongtengen in Yogyakarta City, with a significance value on the results showed $(\mathrm{p}=0.016$ 
$<0.05$ ) Sharmila and Krishnan (2013) who examined service quality in private hospitals in Chenai India with 385 respondents found that responsiveness was significantly related to patient satisfaction.

The relationship between Tangible Dimensions (Physical Evidence) and Patient Satisfaction states that there is a significant relationship between the dimensions of tangible (physical evidence or direct evidence) and patient satisfaction at the $\mathrm{MCH}$ and FP Polycinic PHC of Gedongtengen in Yogyakarta City, with significance values on the results $(p=0.001$ $<0.05)$. Likewise Susmaneli and Triana in the study of 92 respondents who used cross-sectional designs about the Quality Dimensions of Midwifery Services for Patient Satisfaction in the Jampersal Program at Rokan Hulu General Hospital Pekan Baru found that the physical evidence dimension ( $\mathrm{p}=0.003$ ) was significantly related to patient satisfaction (Susmaneli, 2014).

\section{CONCLUSION}

Respondents' characteristics were based on the age of the respondents in the $\mathrm{MCH}$ and FP Polyclinic PHC of Gedongtengen in Yogyakarta City, most of whom were included in the age group of more than 25 years, with the category of high school education, and housewife work.

There is a relationship between the dimensions of reliability, empathy, assurance, responsiveness, and tangible (physical evidence or direct evidence) with patient satisfaction athe $\mathrm{MCH}$ and FP Polyclinic PHC of Gedongtengen in Yogyakarta City.

\section{REFERENCES}

Andriani, A. (2017). Hubungan Mutu Pelayanan Kesehatan dengan Kepuasan Pasien di Ruang Poli Umum Puskesmas Bukittinggi. Journal Endurance, 2 (3): 45-52.

Faisal, F.C., Pangemanan, J.M. and Engkeng, S. (2013). Hubungan Antara Pelayanan Perawat dengan Kepuasan Pasien di Instalasi Rawat Inap A Badan Layanan Umum Rumah Sakit Umum Pusat Prof. Dr. R. D. Kandou Kota Manado. Jurnal Kesehatan Masyarakat Universitas Sam
Ratulangi, 1 (9): 254-262.

Handayani, S. (2016). Tingkat Kepuasan Pasien terhadap Pelayanan Kesehatan di Puskesmas Baturetno. Profesi (Profesional Islam) : Media Publikasi Penelitian, 14 (42): 274 - 277.

Khamis, K. and Njau, B. (2014). Patients' level of satisfaction on quality of healthcare at Mwananyamala hospital in Dar es Salaam, Tanzania. BMC Health Services Research, 14 (400): 2403-2412.

Kuntoro, W. and Istiana, W. (2017). Kepuasan Pasien Terhadap Kualitas Pelayanan di Tempat Pendaftaran Pasien Rawat Jalan Puskesmas Kretek Bantul Yogyakarta. Jurnal Kesehatan Vokasional, 2 (1): 140147.

Mumu, L.J. (2015) Analisis Faktor-Faktor Yang Berhubungan Dengan Kepuasan Pasien di Poliklinik Penyakit Dalam RSUP Prof. Dr. R.D. Kandou Manado. JIKMU, 5 (4): 140-149.

Rahman, R. and Kutubi, S. (2013). Assessment ofservice quality dimensions in healthcare industry A study on patient's satisfaction with Bangladeshi private Hospitals. International Journal of Business and Management Invention, 2 (4): 59-67.

Supartiningsih, S. (2017) Kualitas Pelayanan Kepuasan Pasien Rumah Sakit: Kasus Pada Pasien Rawat Jalan. Jurnal Medicoeticolegal dan Manajemen Rumah Sakit, 6 (1): 9-15.

Sharmila, S. and J. Krishnan. (2013) Has the Service Quality in Private Corporate Hospitals Meet the Patient Expectations? A Study About Hospital Quality in Chennai. Asia Pacific Journal of Marketing \& Management, 2 (1): 19-35

Sower, V., Duffy, J., Kilbourne, W., Kohers G. and P. Jones. 2001. The Dimensions of Service Quality for Hospitals: Development and use of the KQCAH Scale. Health Care Manage Rev, 6 (2): 47-59

Susmaneli, H. and Triana, A. (2014). Dimensi Mutu Pelayanan Kebidanan Terhadap Kepuasan Pasien Program Jampersal. Jurnal Kesehatan Masyarakat Nasional, 8 (8): 258-267. 